\title{
OFF INTO THE WET GREEN YONDER: BIRDS AND PLANTS OF A BOREAL BOG
}

by ANTHONY J. ERSKINE*

Each year my studies take me into Canada's north woods, where I investigate the kinds and numbers of birds occupying representative habitats. As I move westward year by year, the forest birds remain much the same, but the wetland birds show striking changes. In 1973, a muskeg off the Dore Lake road, in central Saskat chewan, provided enough excitement to compensate for the effort necessary to get around in it.

From the road there was no sign of a bog. The jack pine-clad sandhills blocked off the view westward, and a low black spruce forest stretched away beyond the pond to the east. The map told us a muskeg lay there, so we followed an old trail off through the spruces. The ground rapidly became spongy underfoot and we had to adopt a slow, moose-like gait, each foot lifted out of the clinging moss in turn and placed in again farther on, without haste. Waders were a necessity, not for deep water but because of the splashes that would quickly soak one above lower boots. Here the spruces had given way to lichen-draped tamaracks. Only a few twigs on each tree showed the new green of fresh needles amid the gray and gray-green and buffy pendants of the lichens, which swathed trunk and branch alike. Within a quarter-mile, the muskeg opened to the north through the trees. Now the tamaracks were farther apart, and gave

Canadian Wildlife Service,

Dttawal. Ontario.

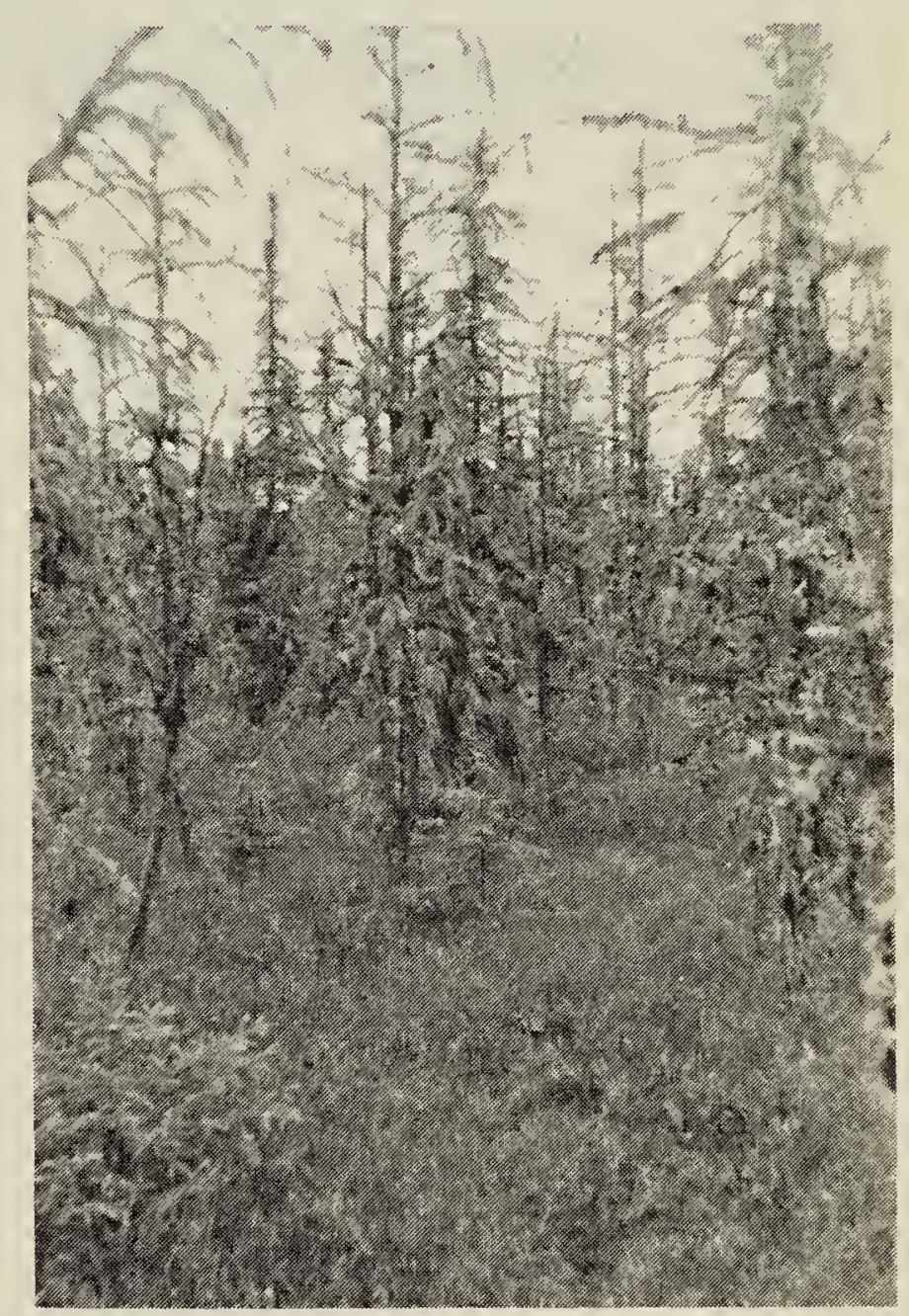

A. J. Erskine Closed tamarack stand.

way to a green sedge meadow with clumps of dwarf birch, all standing in water.

On May 22-23 we marked out a study plot in the western part of the bog. During the next 7 weeks I surveyed this area nine times. Birds were my chief interest, but I also took note of the more striking plants. On the last two surveys I listed all the plants found on 21 sample areas uniformly scattered over the study plot. The 


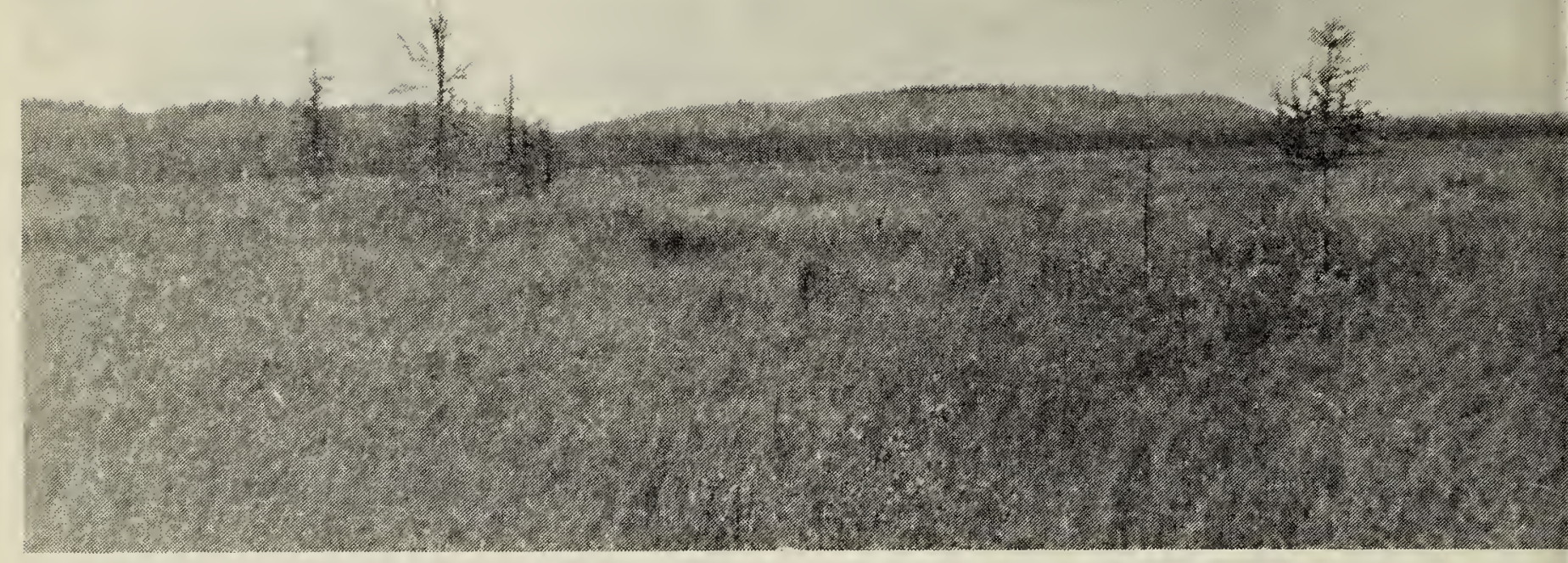

Open bog.

A. J. Erskine

numerical results are summarized and discussed below.

Description of the study area: Size - 52 acres $(21$ ha). The western third is an open stand of tamaracks, mostly 2 to 3 inches in diameter and 10 to 15 feet tall, with about $15 \%$ of black spruces of similar size intermingled. The eastern part is a wet sedge meadow with scattered dwarf birches up to 2 feet high. The intervening area has widely scattered tamaracks and denser shrub cover of dwarf birch and leatherleaf. Here and there in the open areas are firmer ridges rising a foot or so above water level, supporting black spruce and tamarack, cover comparable to that of the western part. Tree density overall averages about 320 trees per acre, counting only those 2 inches in diameter or larger, but the western third probably averages about twice this figure while the eastern part is virtually treeless. Plant species identified on the plot are listed in Table 1, with their frequency of occurrence in the vegetation samples.

The bird census: Coverage - May 29, 31; June 4, 7 and 11, 13, 22, 24, 29 and July 7 ; nine complete surveys, totalling about 29 hours. Skies were cloudy on all but two surveys, with drizzle on three visits. Winds were force 3
(Beaufort scale) or less except briefly on two surveys. Temperatures ranged between $43^{\circ}$ and $84^{\circ} \mathrm{F}$ during the surveys. The estimated numbers of pairs, singing males, broods, or territories of the birds found are shown in Table 2. Remarks: This bog differed both in vegetation and birds from others I have surveyed in past years. Unlike all the others, this bog was based on mosses other than the usual peat-moss. Peat-mosses were scarce and largely confined to the drier areas, where black spruce occurred with cloudberry and bog laurel. Most of the plants (other than mosses and sedges) will be familiar enough to require little comment, but the swamp-pink deserves special mention. This showy, deep pink orchid is not even listed by most floras as occurring in Saskatchewan. It was first collected in this province near Lake Athabasca in 1962 by George Argus, who tells me that it should be anticipated in suitable habitats (such as this one) across the northern half of the province. It was scarce here, as I found only five plants, all within about 20 yards of each other, by one of the spruce ridges along the edge of the open area.

The variety of water and shore birds in this bog was much greater than in others I have studied. I found no nests, 
but breeding could often be inferred from the frantic alarm calls of the parents. The shorebirds in particular often escorted me back and forth along the grid lines most of the way across the plot. Details are given below for those species of which the observations did not allow mapping of clear-cut territories.

Canada Goose: One bird on each of the first four visits, twice flushed from the plot; on June 4 it was seen on the ground to the east, skulking as if leading a brood.

Marsh Hawk: Single birds on June 4 and July 7 , mobbed by smaller birds each time; not seen elsewhere within 15 miles of plot, so apparently associated with this habitat.

Kestrel: Once seen perched on the plot and once flying across, mobbed by Rusty Blackbirds both times; a Kestrel was seen regularly along the road $1 / 2$ mile northwest, so this bog was probably included in its home range.

Sandhill Crane: Two birds were flushed twice from the plot, and heard bugling (in similar habitat) to the nor theast on three other dates; a third was heard to the west (beyond the road) once.

Snipe: Up to four birds "sang" over or within earshot of the plot, and individuals were flushed occasionally; their activity areas were not discrete, but it seems unlikely that more than two pairs nested on the plot.

Solitary Sandpiper: Two birds were seen, expressing great agitation, on June 29. They escorted me back and forth, ranging over an area about 300 $\mathrm{m}$. by $200 \mathrm{~m}$. I judge that they nested elsewhere and had brought their brood to the plot since my previous visit; they had moved away before I returned on July 7 .

Greater Yellowlegs: These probably nested on the plot, where they were seen from May 22. Only "song flights" and occasional agitated calling were noted until June 13, when the birds began to escort me around the plot. On succeeding visits this activity extended
Table 2. Estimated breeding birc population of muskeg study area south of Dore Lake, Saskatchewan, 1973.

Species

Pairs, males, brood or territorie

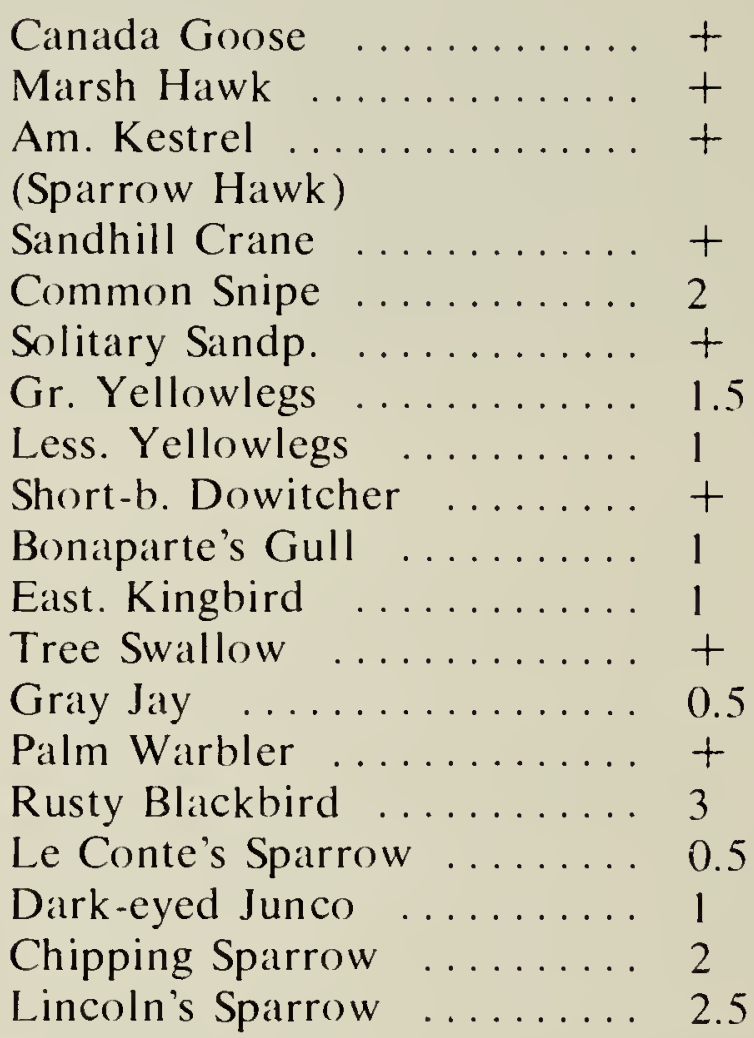

Total: 19 species

about 18 pairs

Density: $35 \mathrm{pr} . / 100$ acres $\left(86 / \mathrm{km}^{2}\right)$

$t=$ less than 0.5 territory.

far beyond the areas where the birds had formerly ranged. Presumably they later led their brood(s) away, as no birds were detected on the last two surveys.

Lesser Yellowlegs: As with the Solitary Sandpiper, these birds probably nested off the plot, and first appeared along its eastern edge on June 11 . Their young likely hatched in the next week. as they first escorted me around the plot on June 22; this continued up to my last visit, but was then centred just off the plot to the east.

Short-billed Dowitcher: One bird appeared and objected to my presence, in the same restricted area, on June 22 and 24. Like the other shorebirds, it perched in the trees and called 
repeatedly, though its excitement was expressed in less frenzied fashion than in the other species. These birds have been found breeding in Saskatchewan near Kazan Lake, about 75 miles to the northwest, and this record extends the known range.

Bonaparte's Gull: At least four adults were present, often one pair near each end of the plot, although all four were seen in flight together once. They "buzzed" me frequently, and sometimes were seen resting in treetops, the latter usually off the plot.

Tree Swallow: One bird sang over or just off the plot to the west on four dates and twice was seen perched there. Its activity area certainly included part of the plot, although no trees large enough for nest sites occurred there.

The other passerine birds were typical of this habitat and exhibited territorial behaviour, allowing the mapping of song posts of individual birds. Rusty Blackbirds were more difficult than other species, since these larger birds could be detected at great distances in this open habitat. The Eastern Kingbird, Rusty Blackbirds and junco were all near the north end of the plot, where ridges and clumps of trees provided a better interspersion of open and wooded areas, whereas all
Chipping Sparrows were in the western part. Lincoln's Sparrows occurred all along the edge between closed and open areas.

In summing up my impressions of this area, I must emphasize that the density of birds is very low, much lower than either in nearby forested areas or in marshes farther south. The variety, however, is quite impressive, and even the species which occurred only sporadically on such a small plot were easily detected in this open habitat. There must be few other areas, south of the Arctic tundra, with five species of (probably) breeding shorebirds. Some bird species reach the limits of their breeding ranges in such places, as do a number of plants, most of which, however, are less striking than the Arethusa orchid found here. The effort needed to get around in the muskeg habitat will deter many naturalists, but it offers rewards to those willing to plunge in.

I wish to thank R. Ireland and George Argus, respectively, for their help in naming the mosses and the flowering plants. Calvin Cuthbert helped in marking and measuring the plot.

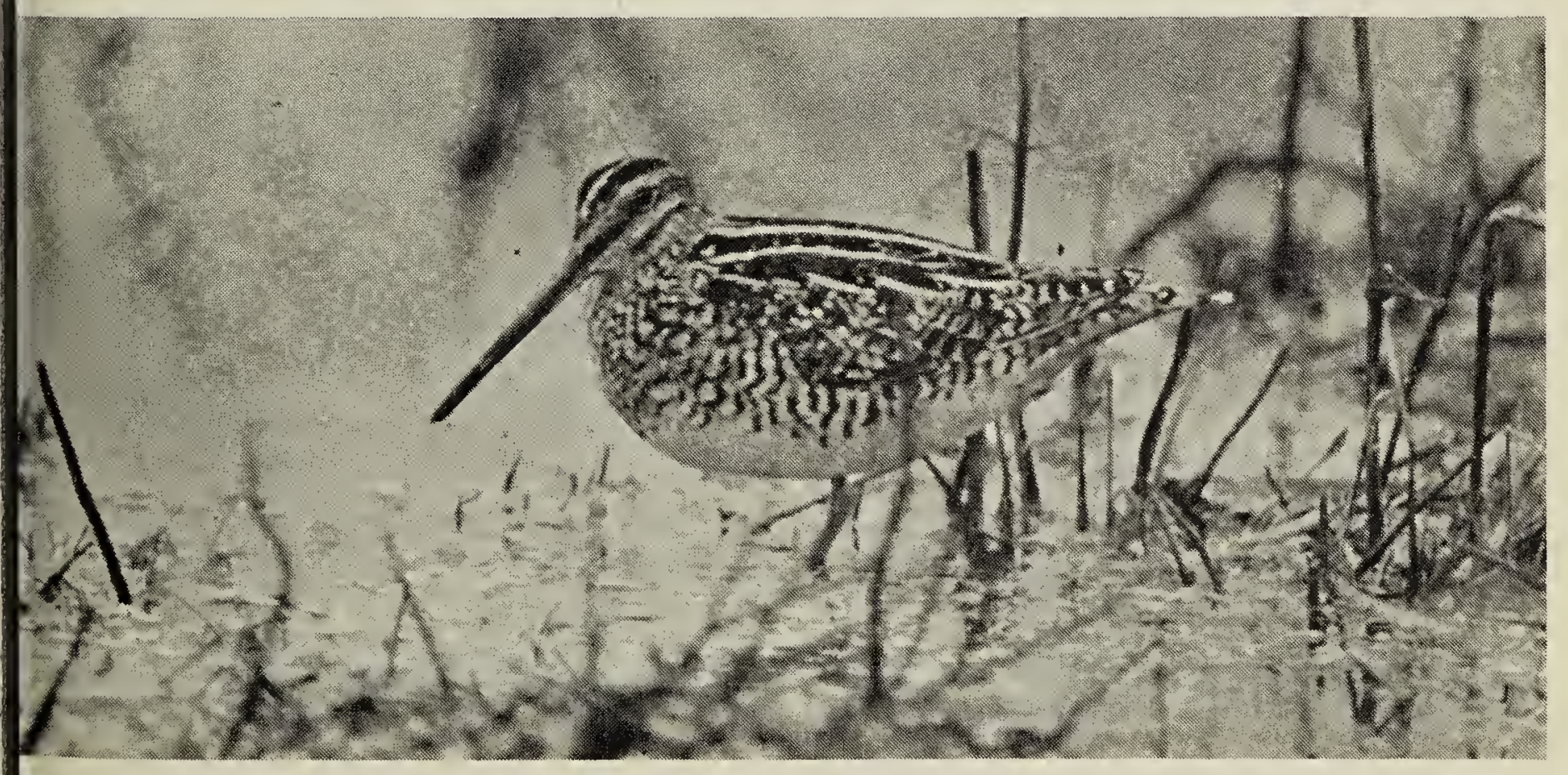

Common Snipe.

Fred Lahrman 